\title{
Effects of Super-Absorbent Polymer Application on Yield and Yield Components of Rapeseed (Brassica napus L.)
}

\author{
Fariborz SHEKARI*, Abdollah JAVANMARD, Amin ABBASI \\ University of Maragheh, Faculty of Agriculture, Department of Agronomy and Plant Breeding, Iran; shekari fb@yahoo.com ("corresponding author); \\ A.javanmard@maragheh.ac.ir; a.abbasi25@yahoo.com
}

\begin{abstract}
Limitation of water resources and its great impact on agricultural and natural resources play a crucial role in the efficiency of water use. Applying super absorbent polymer to the soil may be one of the methods to minimize the stress of weather dryness in arid and semi-arid regions. In order to evaluate the effects of hydrophilic polymer application on yield and water use efficiency of rapeseed plants, an experiment was conducted under field condition in 2012 at the Research Farm of the Faculty of Agriculture, University of Maragheh. Treatments' factors were: (i) 3 super absorbent polymers (SAP) (Taravat A200) levels of 0 (without application), 75 and $150 \mathrm{~kg} \mathrm{ha}^{-1} \mathrm{~A} 200$ application, (ii) three irrigation levels of 80, 120 and $180 \mathrm{~mm}$ evaporation from class A basin in main plots, (iii) two cultivars 'Hyola 401' and 'RVS' in sub plots as factorial split plot combination based on completely randomized block design with three replications. The results showed that in all of the measured traits within the experiment there were significant differences between SAP levels. Furthermore, increasing irrigation interval led to an increase in a thousand seeds' weight, but decreased seed yield. Increasing water stress raised seed oil percent and infertile silique and subsequently resulted in reduced oil yield. 'Hyola 401' was more susceptible to embryo abortion compared with 'RVS'. As a conclusion of the research, SAP (A200) application in quantities smaller than $75 \mathrm{~kg} \mathrm{ha}^{-1}$ may be recommended for rapeseed production under field condition.
\end{abstract}

Keywords: drought, hydrogel, irrigation, oil yield, water-holding capacity, water stress

\section{Introduction}

Synthetic polymers in the form of crystals or tiny beads are available under several trade names as super absorbent polymers, root watering crystals and drought crystals; they are collectively known as hydrogels. They can absorb and retain 1,000 times more water or aqueous solutions than their original size and weight (Farrell et al., 2013). The incorporation of super absorbent polymers (SAPs) into soil improved soil physical properties (El-Amir et al., 1993), enhanced seed germination, plant emergence, crop growth and yield (Yazdani et al., 2007) and reduced the irrigation requirement of plants (Taylor et al., 1986).

In arid and semiarid regions, drought stress is the main factor limiting crop growth and productivity (Todorov et al., 1998). Efficient management of soil moisture is critical for agricultural production in areas with scarce water resources (Eneji et al., 2013). Iran contains both arid and semiarid regions and drought stress is one of the major environmental stresses, restricting crop production in the country (Jabbari et al., 2013). The amelioration of drought stress by application of SAPs has been documented in several studies (Yazdani $e t$ al., 2007; Islam et al., 2009; Li et al., 2014). The SAPs improved soil porosity, structure and water-holding capacity (Karimi et al., 2009). Also, the use of hydrophilic polymer materials as carrier and regulator of nutrient release minimized undesired fertilizer losses and sustained considerable plant growth (Mikkelsen, 1994). SAPs also significantly increased the soil water content (SWC) and soil maximum hygroscopic moisture (SMHM) in the booting and filling stages, but had no effect on the soil available waterholding capacity (AWC) compared with the control in the filling stage (Li et al., 2014). Ahmad and Verplancke (1994) reported an improvement in germination and biomass production of clover, lettuce and ryegrass in dune sand with gel amendment. Seedling emergence rate and dry seedling weight in lettuce, tobacco and cotton increased in soil amended with hydrogel (Wallace and Wallace, 1986). Woodhouse and Johnson (1991) have shown varying degrees of improvement in the germination and establishment of different plant species. The highest increase in seed yield, total dry matter (TDM), leaf area index (LAI), crop growth rate (CGR) and harvest index (HI) were achieved by Yazdani $e t$ al. (2007) with a dose of $225 \mathrm{~kg} \mathrm{ha}^{-1}$ polymer compared with the control (without polymer). These results indicated that the application of super absorbent polymer increased all the above growth and yield attributes (Yazdani et al., 2007).

Rapeseed (Brassica napus L.) is a cosmopolitan oil bearing plant. Its oil is used primarily for human foods, but has also some industrial applications. Worldwide, rapeseed production is of approximately 62.4 million tons and covers a 
362

total area of 33.6 million hectares (FAO, 2011). Rapeseed is one of the most important industrial crops in Iran. A major challenge for the production of rapeseed in Iran is the lack of uniform stand establishment of the plants due to poor water resources and dry soil conditions (Mwale et al., 2003). Two overlapping growth stages are considered to influence rapeseed yield and yield components: silique formation and seed number per silique. Several factors, including low water availability, during those critical periods negatively influence siliques number per plant and the number of seeds per silique. There is evidence that apart from environmental factors (such as drought stress), limited photosynthate had great impact on seed number per silique for rapeseed plants (Puma and Panin, 1999).

In a previous study, water deficit stress either in the vegetative growth stage or during flowering and/or seed filling stage, led to a significant decline in seed number per unit area and reduced yield (Ahuja et al., 2008). Seed weight per unit area is a more variable factor of rapeseed, genotypes being easily influenced by environmental factors. Commonly, there is a linear relationship between time course from flowering (beginning to ending of this stage) and seed weight. Seed development period of rapeseed is between 35 to 55 days. This period is mainly dependent on water and photosynthate availability (Rao and Mendham, 1991).

Due to the extension of drought in Iran and the importance of rapeseed cultivation in the country, the objective of this study was to evaluate the effect of super absorbent application in order to reduce the effects of drought stress. Recently, due to high efficiency, low cost and easy availability of Taravat A200, as common SAP in Iran, the use of this material is more spread. It should be noted that the A200 used in this research composed of acryl amide (AM), acrylic acid (AA) and potassium acrylate.

\section{Materials and Methods}

The experiment was conducted at the Research Farm of the Faculty of Agriculture, University of Maragheh, Iran, during 2012-2013 (from autumn of 2012 to spring of 2013). Two rapeseed (Brassica napus L.) cultivars namely 'Hyola 401' and 'RVS' (sub plots) were employed for evaluation of combinations of $0,75,150 \mathrm{~kg} \mathrm{ha}^{-1}$ soil based with Taravat A200 (1-2 mm granular size) and application of three irrigation levels: 80, 120 and $160 \mathrm{~mm}$ evaporation from class A pan, as factorial split plot based on randomized complete block design with three replications. Main plots (strips) were irrigation levels of $\mathrm{I}_{1}=80$ $\mathrm{mm}, \mathrm{I}_{2}=120 \mathrm{~mm}$ and $\mathrm{I}_{3}=160 \mathrm{~mm}$ evaporation from class A pan. Water penetration value was determined by double ring and irrigation duration was calculated by the Blaney-Criddle method. Three levels of SAP (A200) at $S_{1}=$ Control (without application of SAP), $S_{2}=75 \mathrm{~kg} \mathrm{ha}^{-1}, S_{3}=150 \mathrm{~kg} \mathrm{ha}^{-1}$ super absorbent, were applied into $15 \mathrm{~cm}$ depth of furrows prior to planting. Physical and chemical characteristic of super absorbent polymer were as presented in Table 1 . The SAP amendment used in this study was produced by the Rahab Resin Co. Ltd., under license of the Iran Polymer and Petrochemical Institute. It was a white granular powder with $90 \%$ active ingredient, 75 $1,000 \mu \mathrm{m}$ particle size and $0.60 \mathrm{~g} \mathrm{~cm}^{-3}$ bulk density, which swells to form a gel in water. After calculation, the necessary super absorbent amounts were poured separately into each pail and sufficient water was added. Thirty minutes later, the super absorbent had already absorbed completely the water and was slowly and accurately poured on the whole plot. Each plot was consisted of 5 rows of $5 \mathrm{~m}$ in length and $3 \mathrm{~m}$ width. There was a distance of $1.8 \mathrm{~m}$ between strips and $3 \mathrm{~m}$ between sub plots.

The soil of the experimental site was a clay loam, with a montmorillionite clay type, $10 \%$ of neutralizing substances low in nitrogen $(0.06-0.07 \%)$, low in organic matter $(0.56-0.60 \%)$, and alkaline in reaction with a $\mathrm{pH}$ of 7.2 and $\mathrm{EC}=0.66 \mathrm{dSm}^{-1}$.

The method of irrigation was siphons and the amount of water used was measured by 2 inch contour.

Planting of rapeseed was done after the application of super absorbent. Plant density was 150 seed per $\mathrm{m}^{2}$. All common tillage practices such as weeding and disease control were carried out on plants. Plants harvest was carried out on July 2013. Observations were carried out on 2 central rows and $0.5 \mathrm{~m}$ from both ends of the rows was left not studied as it represented the border effect.

The following measurements were carried out: seed yield (seeds were separated and weighted from individual plots (14\% moisture)), the number of siliques per plant (18 plants of every individual plot were selected and the number of siliques in every plant were countered (with at least one seed)), the number of seeds per silique (18 plants of every individual plot selected and the number of seeds were countered from 5 siliques in every plant) and 1,000-seed weight (seed counter was used to count the number of 100-seed). Seed oil quantity was determined by succelet method.

All data were analyzed by using the SAS software (SAS Institute Inc., 1997). Each treatment was analyzed in three replications. When ANOVA showed significant treatment effects, the Duncan's multiple range test was applied to compare the means, at $\mathrm{p}<0.05$.

Table1. Super absorbent polymer (Taravat A200) characteristics

\begin{tabular}{ccccccc}
\hline Color & $\begin{array}{c}\text { Humidity } \\
(\%)\end{array}$ & Toxics & $\begin{array}{c}\text { Density } \\
\left(\mathrm{g} / \mathrm{cm}^{3}\right)\end{array}$ & $\mathrm{pH}$ & $\begin{array}{c}\text { Water } \\
\text { soluble }\end{array}$ & $\begin{array}{c}\text { Dimension } \\
(\text { micrometer })\end{array}$ \\
\hline White & $3-5$ & No & 1.5 & $6-7$ & No & $50-150$ \\
\hline
\end{tabular}

\section{Results and Discussion}

The results showed that super absorbent application had significant effects on yield and yield components of rapeseed (Table 2). The results of the current study showed that super absorbent application under control condition and moderate stress (80 and $120 \mathrm{~mm}$ evaporation from class A basin, respectively) led to prominent increase of the siliques number per plant, while under severe stress $(160 \mathrm{~mm}$ evaporation from class A pan), only the application of $75 \mathrm{~kg} \mathrm{ha}^{-1}$ of super absorbent could increase this trail amount significantly (Table 3). Li et al. (2014) noted that the addition of SAPs promoted the formation of macro soil aggregates (particle size $>0.25 \mathrm{~mm}$ ) and soil bacterial abundance under winter wheat cultivation. The results showed that the application of SAPs did not lead to detectable adverse effects on the soil microbial community and might even enhance soil microbial activity.

Probably in the current experiment also, A200 as a super absorbent, had positive effects upon increasing soil water availability and concomitantly improved siliques number per plant. Application of $150 \mathrm{~kg} \mathrm{ha}^{-1}$ super absorbent significantly increased siliques number per plant for 'Hyola 401' cultivar, but not for 'RVS' (Table 4). There was no significant difference between cultivars with low amounts of super absorbent application, but for the higher quantity of super absorbent application the difference between cultivars was significant. 
Table 2. Analysis of variance of Brassica napus seed characteristics

\begin{tabular}{|c|c|c|c|c|c|c|}
\hline \multicolumn{6}{|c|}{ F-value } & \multirow[b]{2}{*}{ S. O. V. } \\
\hline Seed oil yield & Seed yield & $\begin{array}{c}1,000 \text {-seed } \\
\text { weight }\end{array}$ & Seed per silique & Siliques per plant & D.F & \\
\hline ns & * & $\mathrm{ns}$ & * & Ns & 2 & Replication \\
\hline * & ** & $\mathrm{ns}$ & ns & ** & 2 & Irrigation \\
\hline * & * & * & * & Ns & 2 & SAP \\
\hline \multirow[t]{2}{*}{ ns } & ns & ** & ** & ** & 4 & SAP*Irrigation \\
\hline & & & & & 16 & Error A \\
\hline ns & ns & ns & $\mathrm{ns}$ & Ns & 1 & Cultivar \\
\hline ns & ns & ns & ns & * & 2 & Cultivar*SAP \\
\hline ns & ns & ns & ** & $\mathrm{Ns}$ & 2 & Cultivar Irrigation \\
\hline \multirow[t]{2}{*}{ ns } & $\mathrm{ns}$ & ns & ns & Ns & 4 & Cultivar*SAP*Irrigation \\
\hline & & & & & 18 & Error B \\
\hline
\end{tabular}

Table 3. Siliques number per plant, seed number per silique and 1,000-seed weight as influenced by super absorbent rate and irrigation level

\begin{tabular}{|c|c|c|c|c|}
\hline \multirow[b]{2}{*}{1,000 -seed weight $(\mathrm{g})$} & \multirow[b]{2}{*}{ Seed per silique } & \multirow[b]{2}{*}{ Siliques per plant } & \multicolumn{2}{|c|}{ Treatments } \\
\hline & & & $\begin{array}{c}\text { Irrigation } \\
\text { levels }(\mathrm{mm})\end{array}$ & $\begin{array}{c}\text { Super absorbent } \\
\left(\mathrm{kg} \mathrm{ha}^{-1}\right)\end{array}$ \\
\hline $3.85^{\mathrm{cd}}$ & $25.2^{\mathrm{e}}$ & $130^{\mathrm{e}}$ & 80 & \\
\hline $3.80^{\mathrm{d}}$ & $25.8^{\mathrm{de}}$ & $135^{\mathrm{de}}$ & 120 & Non-application \\
\hline $3.93^{\text {bcd }}$ & $27.0^{\text {cd }}$ & $137^{\mathrm{cd}}$ & 160 & \\
\hline $3.86^{\mathrm{cd}}$ & $28.3^{\mathrm{bc}}$ & $140^{\mathrm{bc}}$ & 80 & \\
\hline $3.98^{\mathrm{bc}}$ & $30.3^{\mathrm{a}}$ & $160^{\mathrm{a}}$ & 120 & 75 \\
\hline $4.01^{\mathrm{b}}$ & $29.0^{\mathrm{ab}}$ & $150^{\mathrm{ab}}$ & 160 & \\
\hline $3.97^{\mathrm{bc}}$ & $30.8^{\mathrm{a}}$ & $165^{a}$ & 80 & \\
\hline $4.04^{\mathrm{b}}$ & $30.2^{\mathrm{a}}$ & $180^{\mathrm{a}}$ & 120 & 150 \\
\hline $4.32^{\mathrm{a}}$ & $27.0^{\text {cde }}$ & $136^{\text {cde }}$ & 160 & \\
\hline
\end{tabular}

Means within a column followed by the same letters are not significantly different based on Duncan's test at $5 \%$ probability level

There was an association between siliques number per plant and seed number per silique. Water deficit during silique formation period considerably reduced siliques number/plant. On the contrast, any delay in water deficit treatment beyond silage formation stage resulted in substantial decline of seed number per siliques. Meanwhile, complementary or regular irrigation of rapeseed fields increased siliques numbers per plant due to increased leaf area during flowering period, and thus more assimilates availability for leaves and/or shoot development and therefore raised silique formation.

Several studies revealed that in rapeseed plants there is strong competition for assimilates partitioning between developing siliques and seeds (Aljaloud et al., 1996; Nielson, 1997; Leilah et al., 2000; Zarei et al., 2010). This competition is more severe during stress conditions, leading to seed yield loss due to siliques shedding. The higher number of siliques/plant under shorter stress intervals could be attributed to higher number of flowers/plant (Zarei et al., 2010). The constant stress in flowering and silique development stages caused the loss of fertility, no siliques formation and higher percent of siliques abscission to some extent (Ardestani et al., 2011). McPherson et al. (1987) noted that water deficit stress during late season went to shedding of up to $50 \%$ of siliques.

Under control irrigation treatment any increase in super absorbent level resulted in increased silique seed content (Table 3). In $120 \mathrm{~mm}$ evaporation from class A basin (moderate water deficit) there was no difference between the two super absorbent application levels and the least seed number per silique belonged to control treatment (without super absorbent application). Under severe water stress conditions, application of $75 \mathrm{~kg} \mathrm{ha}^{-1}$ super absorbent enhanced seed number, but no statistical difference was observed between control (without super absorbent employment) and $150 \mathrm{~kg} \mathrm{ha}^{-1}$ super absorbent application.

Water availability especially during flowering and silique development period is favorable for raising siliques' seed content and consequently seed yield per unit area. Complementary, irrigation of rapeseed is favored for seed number in silique as well (Nielsen, 1996). Pazuki (1996) reported that under stress conditions, reduced flower formation, decreased number of fertile flowers, as well as increased respiration rates were the main reasons for lessened seed number in siliques.

Thousand seed weight had a positive relationship with the super absorbent levels. Furthermore, any increase in irrigation interval led to increased thousand seed weight. Interactive effects of super absorbent $\times$ irrigation levels showed that any increase in super absorbent level under severe stress condition (160 mm evaporation from class A basin) raised one thousand seed weight (Table 3).

The beneficial effects of hydrophilic polymers on plant drought tolerance are due to the supplementary water derived from the hydrophilic polymer granules that improved water availability in the drying soil (Shi et al., 2010). As a consequence, the plant roots can take up water from the polymer fragments. Hence, the soil drying-induced leaf injury was consequently alleviated (Shi et al., 2010). At the same time, $75 \mathrm{~kg} \mathrm{ha}^{-1}$ super absorbent level combined with acute water stress produced a low number of large seeds. Pazuki (1996) noted that in rapeseed production, reduction of irrigation from $85 \mathrm{~mm}$ to $45 \mathrm{~mm}$ and/or decrease in water availability led to diminished one thousand seed weight. The 
364

scientist claimed reduced water and nutrients absorption and hence weakened photosynthesis and assimilates partitioning were the principle support for reduced thousand seed weight under water deficit condition.

Super absorbent application substantially influenced seed yield of rapeseed plants (Table 5). Seed number per silique was positively influenced by super absorbent application (Table 5). 'Hyola 401' cultivar within the $80 \mathrm{~mm}$ irrigation level had significant less seeds per silique than the rest of the treatments in the experiment (Table 6). Leaf stomatal conductance (Gs), transpiration rates (TRN) and net photosynthetic rates $\left(\mathrm{P}_{\mathrm{n}}\right)$ of the plants markedly increased with super absorbent application (Shi et al., 2010). The current results were consistent also with those of Arbona $e t$ al. (2005) and Viero and Little (2006), in which the application of hydrophilic polymers improved the growth performance of Eucalyptus (Viero and Little, 2006) and Citrus (Arbona et al., 2005) under water-deficient conditions. However, no significant difference was observed between 75 and $150 \mathrm{~kg} \mathrm{ha}$ 1 super absorbent application. In contrast, seed yield was negatively related with the increase in irrigation intervals (Table 7). In order to reach the optimum yield of rapeseed plant it is essential to restore irrigation immediately after 80 mm evaporation from class A basin.

Seed yield was strongly correlated with seed oil content and yield. Enlarged irrigation intervals led to the reduction of seed oil content and yield. Puma and Panin (1999) reported that growing season precipitation and temperatures were the appropriate indices for prediction of rapeseed yield potential. Deep root distribution and simultaneously high potential of rapeseed roots for utilization of sub-soil level water resources, as well as low dependence of this plant upon precipitation, are the main advantages of rapeseed production systems in arid regions. There is evidence that rapeseed has the potential to produce suitable yields only with soil moisture resources (Puma and Panin, 1999). The main irrigation needed stages of rapeseed production under arid regions are during seed sowing time, plantlets emergence and flowering periods. Nilsen (1996) studied the effect of draught on rapeseed and reported that water deficit during seed filling periods resulted in minimum seed yield, due to low branching potential, reduced silique number per branches and lessened seed number per siliques. Moreover, competition for water, nutrients and photosynthates between developing silique walls and maturing seeds, are another yield restrains that lead to silique abscission (McPherson et al., 1987). In general, adequate water availability especially during flowering period and silique development time would be the most effective criterion towards the improvement of seed yield by increasing seed number per silique (Rao and Mendham, 1991).

Super absorbent supply enhanced seed oil yield of plants. There was no statistical difference between 75 and $150 \mathrm{~kg} \mathrm{ha}^{-1}$ super absorbent application (Table 5). Oil yield decreased in response to the increase in irrigation intervals (Table 7). Morgan (1995) observed that irrigation cease during reproductive growth stage substantially reduced oil content. Furthermore, oil yield of rapeseed increasingly diminished under water deficit conditions.

There was a positive strong correlation between seed yield and seed oil content and yield, so that any decrease in seed yield under water stress conditions lead to seed oil content and yield loss and vice versa (Table 7 ). The results showed
Table 4. Siliques number per plant as influenced by super absorbent rate and cultivar

\begin{tabular}{ccc}
\hline \multirow{2}{*}{ Siliques per plant } & \multicolumn{2}{c}{ Treatments } \\
\cline { 2 - 3 } & Cultivar & $\begin{array}{c}\text { Super absorbent } \\
\left(\mathrm{kg} \mathrm{ha}^{-1}\right)\end{array}$ \\
\hline $140^{\mathrm{b}}$ & 'Hyola 401' & Control \\
$142^{\mathrm{b}}$ & 'RVS' & \\
$141^{\mathrm{b}}$ & 'Hyola 401' & 75 \\
$140^{\mathrm{b}}$ & 'RVS' \\
$210^{\mathrm{a}}$ & 'Hyola 401' & 150 \\
$141^{\mathrm{b}}$ & 'RVS' & 150 \\
\hline Means followed by the same letters are not significantly different based on
\end{tabular}
Duncan's test at $5 \%$ probability level

Table 5 . Number of seeds per silique, seed yield and seed oil yield by super absorbent rate

\begin{tabular}{cccc}
\hline $\begin{array}{c}\text { Seed oil yield } \\
(\mathrm{t} \mathrm{ha})\end{array}$ & $\begin{array}{c}\text { Seed yield } \\
\left(\mathrm{t} \mathrm{ha} \mathrm{h}^{-1}\right)\end{array}$ & $\begin{array}{c}\text { Seed number } \\
\text { per silique }\end{array}$ & $\begin{array}{c}\text { Super absorbent } \\
\left(\mathrm{kg} \mathrm{ha}^{-1}\right)\end{array}$ \\
\hline $1.30^{\mathrm{b}}$ & $3.31^{\mathrm{b}}$ & $26.5^{\mathrm{b}}$ & Control \\
$1.46^{\mathrm{a}}$ & $3.79^{\mathrm{a}}$ & $28.4^{\mathrm{a}}$ & 75 \\
$1.49^{\mathrm{a}}$ & $3.85^{\mathrm{a}}$ & $28.5^{\mathrm{a}}$ & 150 \\
\hline Means within a column followed by the same letters are not significantly different
\end{tabular}
based on Duncan's test at $5 \%$ probability level

Table 6. Interaction effect between irrigation level ( $\mathrm{mm})$ and cultivars on seed number per silique

\begin{tabular}{ccc}
\hline $\begin{array}{c}\text { Seed number per } \\
\text { silique }\end{array}$ & \multicolumn{2}{c}{ Treatments } \\
\cline { 2 - 3 } $23.9^{\mathrm{b}}$ & Cultivar & Irrigation $(\mathrm{mm})$ \\
\hline $28.5^{\mathrm{a}}$ & 'Hyola 401' & 80 \\
\hline $29.8^{\mathrm{a}}$ & 'RVS' & \multirow{2}{*}{120} \\
$28.8^{\mathrm{a}}$ & 'Hyola 401' & \\
\hline $29.2^{\mathrm{a}}$ & 'RVS' & 160 \\
$29.3^{\mathrm{a}}$ & 'Hyola 401' & \\
\hline
\end{tabular}

Means followed by the same letters are not significantly different based on Duncan's test at $5 \%$ probability level

Table 7. The effect of irrigation ( $\mathrm{mm}$ ) level on seed yield and seed oil yield

\begin{tabular}{ccc}
\hline $\begin{array}{c}\text { Seed oil yield } \\
\left.(\mathrm{t} \mathrm{ha})^{-1}\right)\end{array}$ & $\begin{array}{c}\text { Seed yield } \\
\left(\mathrm{t} \mathrm{ha}^{-1}\right)\end{array}$ & $\begin{array}{c}\text { Irrigation level } \\
(\mathrm{mm})\end{array}$ \\
\hline $1.68^{\mathrm{a}}$ & $3.69^{\mathrm{a}}$ & 80 \\
$1.33^{\mathrm{b}}$ & $3.32^{\mathrm{b}}$ & 120 \\
$1.28^{\mathrm{b}}$ & $3.09^{\mathrm{b}}$ & 160 \\
\hline
\end{tabular}

Means within a column followed by the same letters are not significantly different based on Duncan's test at $5 \%$ probability level

that low evaporative demands $(2-4 \mathrm{~mm})$ of rapeseed plants had no significant impact on seed and oil yield. Contrarily, high evaporative demands $(4-5 \mathrm{~mm})$ meaningfully reduced seed and oil yield. It has been reported that water deficit during silique filling period increased seed oil yield in both loam and sandy soils (Nielsen, 1996).

\section{Conclusions}

Based on the results of this study it can be concluded that super absorbent polymer application in rainfed agriculture increased the quantity and quality of yield. Soil based super absorbent application improved yield components and subsequently seed yield and oil content of rapeseed plants. Also, severe stress led to more infertile siliques due to negative effects of water deficit on seed formation, and hence reduction of seed number per silique and final yield loss. This phenomenon led to the increased partitioning of photo assimilates towards the 
remaining seeds and production of heavier seeds, with higher one thousand seeds' weight. Moderate to severe water deficit increased oil content, but decreased seed production and seed oil yield. This is in conformity with previous findings that water stress impacts seed yield, but it improves oil percent in consequence of increased one thousand seeds weight. There was a significant difference between the two cultivars in the study regarding studied traits. 'Hyola 401' was more susceptible to embryo abortion compared with 'RVS'. Taking into account the overall results of the present experiment, it is worthy of recommendation that similar experiments, with other cultivars, are needed, in order to optimize the rapeseed production dynamics under water deficit conditions of Northwest Iran, as a model region for other dry and semi-dry areas of the world. Additionally, it is advisable that under the geographical and edaphic conditions from Northwest Iran and similar conditions, super absorbent levels smaller than $75 \mathrm{~kg}$ ha${ }^{1}$ are adequate for soil amendment regarding optimum water use efficiency of rapeseed plants. However, this claim needs more detailed and comprehensive studies.

\section{References}

Ahmad M, Verplancke H (1994). Germination and biomass production as affected by salinity in hydrogel treated sandy soil. Pakistan Journal of Forestry 44:53-61.

Ahuja LR, Reddy VR, Saseendran SA, Qiang Yu (2008). Understanding and modeling water stress effects on plant growth processes. ASA-CSSA-SSSA.

Aljaloud AH, Shaikkarimulla G, Al-Hamidi A (1996). Effect of irrigation and nitrogen on yield and yield components of two rapeseed cultivars. Agricultural Water Management 30:57-68.

Arbona V, Iglesias DJ, Jacas J, Primo-Millo E, Talon M, Gomez-Cadenas A (2005). Hydrogel substrate amendment alleviates drought effects on young citrus plants. Plant Soil 270:73-82.

Ardestani HG, Shirani Rad AH, Zandi P (2011). Effect of drought stress on some agronomic traits of two rapeseed varieties grown under different Potassium rates. Australian Journal of Basic and Applied Sciences 5(12):2875-2882.

El-Amir S, Helalia AM, Shawky ME (1993). Effects of acryhope and aquastore polymers on water regime and porosity in sandy soils. Egyption Journal of Soil Science 4:395-404.

Eneji EA, Robiul Islam PAN, Amalu UC (2013). Nitrate retention and physiological adjustment of maize to soil amendment with superabsorbent polymers. Journal of Cleaner Production 52:474-480.

Farrell C, Ang XQ, Rayner GP (2013). Water-retention additives increase plant available water in green roof substrates. Ecological Engineering 52:112-118.

FAO STAT. Brassica napus. (2011). Retrived 2011 from http://www.faostat.fao.org.

Islam MR, Eneji AE, Hu YG, Li J (2009). Evaluation of a water-saving super absorbent polymer for forage oat (Avena sativa L.) production in an arid sandy soil. In: Proceedings of Inter Drought-III Conference. Shanghai
PR China pp 91-92.

Karimi A, Noshadi M, Ahmadzadeh M (2009). Effects of super absorbent polymer (IGETA) on crop, soil water and irrigation interval. Journal of Science and Technology of Agriculture and Natural Resources 12:415-420.

Jabbari H, Akbari GA, Khosh Kholgh Sima NA, Shirani Rad AH, Alahdadi I, Hamed A, Shariatpanahi ME (2013). Relationships between seedling establishment and soil moisture content for winter and spring rapeseed genotypes. Industrial Crops and Products 49:177-187.

Leilah AA, Al-Khateeb SA, Al-Thabet S, Al-Barrak K, AlNaiem A (2000). Response of some canola (Brassica napus L.) cultivars to drought. In Agricultural and Water Resources Development Symposium in the Reign of the Two Holy Mosgues King Fahad Bin Abdulaziz-God's Mercy Be Upon Him pp 28-30.

Li X, He JZ, Hughes JM, Liu YR, Zheng YM (2014). Effects of super-absorbent polymers on a soil-wheat (Triticum aestivum L.) system in the field. Applied Soil Ecology 73:58-63.

McPherson H, Scarth R, Rimmer SR, McVetty PBE (1987). The effect of drought stress on yield determination in oil seed rape. In 7 th International Rapeseed Congress, Poznan pp 822-827.

Mikkelsen RL (1994). Using hydrophilic polymers to control nutrient release. Fertilizer Research 38:53-59.

Morgan JM (1995). Osmo-regulation and water stress in higher plants. Annual Review of Plant Physiology 35:299319.

Mwale SS, Hamusimbi C, Mwansa K (2003). Germination emergence and growth of sunflower (Helianthus annuus L.) in response to osmotic seed priming. Seed Science Technology 31:199-206.

Nielsen DC (1996). Potential of rapeseed as a dry land crop in Northeastern Colorado. In: Janick (Ed). Progress in new crops, ASMS Press, Alexandria, VA pp 281-287.

Nielson DC (1997). Water use and yield of canola under dry land conditions in the central Great Plains. Journal of Production Agriculture 10:307-313.

Pazuki AR (1996). Study and measurement of water stress effect on physiologic characters and different drought resistance indices on two colza cv. PhD Dissertation, IAU Science and Research Ahvaz Branch.

Puma GA, Panin M (1999). Some relationships between number of seeds per pod, seed size, oil content and the effects of selection for these characters in Brassica and Sinapis. Hereditas 46:29-70.

Rao CS, Mendham DG (1991). Drought and water supply. John Hopkins University Press Baltimore.

Shi Y, Li J, Shao J, Deng S, Wang R, Li N, Sun J, Zhang H, Zhu H, Zhang Y, Zheng X, Zhou D, Huttermann A, Chen A (2010). Effects of Stockosorb and Luquasorb polymers on salt and drought tolerance of Populus popularis. Scientia Horticulturae 124:268-273. 
366

Taylor KC, Halfacre RG (1986). The effect of hydrophilic polymer on media water retention and nutrient availability to Ligustrum lucidum. Horticultural Science 21:11591161.

Todorov D, Alexieva V, Karanov E (1998). Effect of putrescine, 4-PU-30 and abscisic acid on maize plants grown under normal, drought, and rewatering conditions. Journal of Plant Growth Regulation 17:197-203.

Viero PWM, Little KM (2006). A comparison of different planting methods, including hydrogels, and their effect on eucalypt survival and initial growth in South Africa. South Southern African Forestry Journal 208(1):5-13.

Wallace A, Wallace GA (1986). Effects of polymeric soil conditioners on emergence of tomato seedlings. Soil Science 141:321-323.
Woodhouse JM, Johnson MS (1991). The effect of a gel forming polymer on seed germination and establishment. Journal of Arid Environments 20:375-380.

Yazdani F, Allahdadi I, Akbari GA (2007). Impact of super absorbent polymer on yield and growth analysis of soybean (Glycine max L.) under drought stress condition. Pakistan Journal of Biological Science 10:4190-4196.

Zarei GH, Shamsi H, Dehghani SM (2010). The effect of drought stress on yield, yield components and seed oil content of three autumnal rapeseed cultivars (Brassica napus L.). Journal of Research in Agricultural Science 6:2937. 